\title{
Sistem Kontrol dan Monitoring Kadar Amonia untuk Budidaya Ikan yang Diimplementasi pada Raspberry Pi 3B
}

\author{
Muhammad Akbar Nugroho dan Muhammad Rivai \\ Departemen Teknik Elektro, Fakultas Teknologi Elektro, Institut Teknologi Sepuluh Nopember \\ e-mail:muhamma_rivai@ee.its.ac.id
}

\begin{abstract}
Abstrak-Kualitas air berpengaruh terhadap tingkat kesehatan ikan, salah satu hal yang harus dijaga adalah kadar amonia. Kadar amonia yang dibiarkan tinggi akan berbahaya terhadap kesehatan ikan, bahkan dapat menyebabkan kematian. Selain itu kualitas air pada perairan harus tetap dijaga karena dapat berpengaruh terhadap laju pengembangbiakan ikan. Pada penelitian ini telah dirancang dan dibuat sebuah sistem kontrol dan monitoring kadar amonia untuk budidaya ikan yang berguna untuk mengukur kualitas air dalam suatu akuarium. Pada dasarnya pengukuran yang dilakukan pada sistem ini memiliki dua variabel utama yang diukur yaitu; tingkat dari $\mathbf{p H}$ air dan kadar amonia. Pada penelitian ini menggunakan dua jenis sensor yaitu sensor $\mathrm{pH}$ dan sensor MQ-135 untuk mengukur kadar amonia yang dihubungkan dengan mikrokontroler Arduino dan Single Board Computer Raspberry. Peralatan ini juga dilengkapi dengan teknologi yang berbasis Internet of Things. Hasil pengukuran akan ditampilkan pada aplikasi Smart Phone. Pada sistem ini nilai pH akan dijaga agar tetap netral $(6,5-7,5)$. Ketika melebihi batas dari nilai tersebut kontrol otomatis akan bekerja dan menyalurkan cairan asam asetat $\left(\mathrm{CH}_{3} \mathrm{COOH}\right)$ menuju akuarium untuk menentralkan nilai pH. Hasil dari pengujian sistem ini menunjukan bahwa sistem dapat melakukan kontrol secara otomatis dan manual. Pada pengukuran data sensor $\mathrm{pH}$ memiliki rata-rata kesalahan $1,88 \%$. Pengontrolan manual dari aplikasi terhadap kondisi aktif dan tidaknya aerator dan filter air memiliki delay sekitar 10 detik. Pada segi monitoring sistem dengan delay sekitar 10 detik, dapat dilakukan melalui aplikasi smartphone sehingga dapat menginformasikan jika terdapat kenaikan kadar $\mathrm{pH}$ dan amonia yang berbahaya untuk ikan.
\end{abstract}

Kata Kunci-Amonia, Sensor pH, Internet of Thing, Basisdata.

\section{PENDAHULUAN}

B UDIDAYA merupakan salah satu kegiatan alternatif dalam meningkatkan produksi perikanan [1]. Untuk menghasilkan komoditas ikan/udang yang unggul, maka proses pemeliharaan harus memperhatikan aspek internal yang meliputi asal dan kualitas benih; serta faktor eksternal mencakup kualitas air budidaya, pemberian pakan, teknologi yang digunakan, serta pengendalian hama dan penyakit [2]. Permasalahan utama yang seringkali ditemukan adalah kualitas air pada tambak atau kolam buatan yang buruk selama masa pemeliharaan. Selain dari kualitas air yang harus dipertahankan kebersihannya, hal lain yang sebenarnya juga sangat sering terjadi dan patut diwaspadai adalah meningkatnya kadar $\mathrm{pH}$ dan kadar amonia pada perairan tambak atau kolam buatan tersebut. Meningkatnya kadar ammonia dan kadar $\mathrm{pH}$ ini dapat menjadi racun tersendiri bagi ikan-ikan tersebut. Kadar amonia yang terlalu tinggi dapat menyebabkan ikan-ikan tersebut tidak dapat mengekstrak energi dari pakan secara efisien sehingga hal tersebut menyebabkan kematian pada ikan. Kematian ini tentunya akan merugikan para pembudidaya ikan. Manajemen kualitas air selama proses pemeliharaan mutlak diperlukan. Beberapa parameter kulitas air yang sering diukur dan berpengaruh pada pertumbuhan udang dan ikan yaitu oksigen terlarut (DO), suhu, $\mathrm{pH}$, salinitas, amonia, dan alkalinitas [3].

Pada penelitian ini akan dibuat sebuah sistem kontrol serta monitoring untuk menjaga kadar $\mathrm{pH}$ dan kadar amonia yang terdapat pada suatu miniplan. Salah satu perangkat yang menggunakan teknologi pengontrol jarak jauh dengan sistem tertanam berbasis ARM (Advanced RISC Machine) adalah Raspberry Pi. Raspberry Pi (disingkat raspi) adalah suatu mini komputer yang dapat bekerja seperti halnya personal komputer [4].

Untuk mengawali penelitian, penulis memulainya dengan mencari informasi tentang pengaruh dari amonia terhadap akuarium. Sumber yang didapat menyebutkan peningkatan amonia diakibatkan oleh pemberian pakan yang terlalu banyak terhadap ikan dapat meningkatkan kadar amonia pada perairan. Konsentrasi dari amonia itu sendiri harus dijaga agar nilainya tetap dibawah $0.2 \mathrm{mg} / \mathrm{l}$ [5]. Selain itu peningkatan suhu serta perubahan $\mathrm{pH}$ juga mempengaruhi peningkatan kadar amonia.

\section{METODE PENELITIAN}

\section{A. Sensor $p H$}

Untuk menjaga agar kualitas air pada akuarium tetap dalam keadaan yang baik, elemen yang harus diperhatikan adalah tingkat keasaman dan kebasaan air di dalam akuarium. Karena $\mathrm{pH}$ yang baik dalam ekosistem kehidupan ikan adalah dengan nilai $\mathrm{pH}$ 6,5 sampai $\mathrm{pH}$ 7,5 [6]. Prinsip kerja dari sensor $\mathrm{pH}$ terdiri dari elektroda yang digunakan untuk mendeteksi ion $\mathrm{H}+$ dari suatu cairan. Pengukuran dilakukan dengan elektroda potensiometrik yang berfungsi untuk memonitor perubahan tegangan yang disebabkan perubahan aktivitas ion Hidrogen $(\mathrm{H}+)$. Elektroda yang digunakan terdiri dari kombinasi tunggal elektroda referensi dan elektroda sensor. Elektroda kombinasi ini memiliki keluaran yang sudah dikalibrasi menjadi $\mathrm{mV}$. Dengan memonitor perubahan tegangan yang disebabkan oleh perubahan aktivitas ion Hidrogen $(\mathrm{H}+)$ dalam larutan, maka $\mathrm{pH}$ larutan dapat diketahui [7]. 


\section{B. Sensor Gas Amonia}

Sensor gas merupakan alat elektronik yang dapat menghasilkan sinyal listrik sebagai fungsi terhadap interaksi dengan senyawa kimia, dalam hal ini gas atau uap senyawa organic [8].

Sensor MQ-135 dapat berfungsi untuk mendeteksi keberadaan gas amonia. Pada dasarnya sensor ini terdiri dari tabung aluminium yang dikelilingi oleh silikon dan di pusatnya terdapat elektroda yang terbuat dari aurum di mana terdapat element pemanasnya. Ketika terjadi proses pemanasan, kumparan akan dipanaskan sehingga $\mathrm{SnO} 2$ keramik menjadi semikonduktor atau sebagai penghantar sehingga melepaskan elektron dan ketika amonia dideteksi oleh sensor dan mencapai aurum elektroda maka output sensor MQ-135 akan menghasilkan tegangan analog.

\section{Internet of Things}

Internet of Things adalah sebuah sistem dimana bendabenda di dunia fisik dapat dihubungkan ke internet oleh sensor, selain itu dikatakan juga sebagai suatu konsep yang bertujuan untuk memperluas pemanfaatan dari penggunaan internet yang tersambung secara terus menerus [9]. Pemanfaatan Internet of Things atau yang biasa disebut dengan IoT ini diterapkan pada penelitian ini agar pada sistem ini memiliki teknologi yang terkini sehingga dapat selalu terkoneksi dengan smartphone pengguna kapan saja. Selain itu penggunaan internet of things ini bertujuan untuk melakukan pemantauan atau monitoring terhadap objek dan melakukan pengendali atau kontrol terhadap objek yang diteliti.

Pada IoT setiap benda harus memiliki sebuah IP address. IP address adalah sebuah identitas dalam jaringan yang membuat benda tersebut bisa diperintahkan dari peralatan lain dalam jaringan yang sama. IP address dalam setiap peralatan tersebut akan dikoneksikan ke jaringan internet

\section{Arduino UNO}

Arduino Uno adalah board mikrokontroler berbasis ATmega328 [10]. Arduino UNO merupakan sub sistem pengolahan data pembacaan untuk sensor $\mathrm{pH}$, dan sensor MQ135. Selain itu pada penelitian ini Arduino memiliki peran dalah melakukan kontrol terhadap kenaikan $\mathrm{pH}$ dan amonia. Pemrograman pada Arduino UNO dilakukan melalui perangkat lunak IDE (integrated development environment) yang dirancang untuk mendukung penggunaan perangkat Arduino [11].

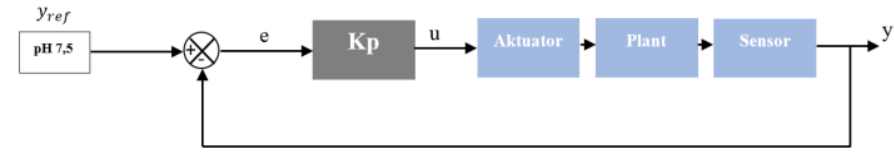

Gambar 1. Diagram blok sistem kontrol.

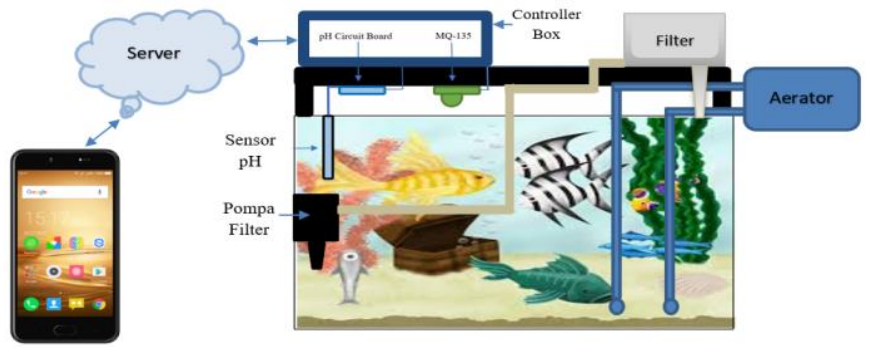

Gambar 2. Skema Sistem Secara Keseluruhan.

\section{E. Pengendali Proporsional}

Kontrol otomatis ini bertujuan untuk menjaga $\mathrm{pH}$ agar tetap dibawah pH 7,5. Pengontrolan ini dilakukan oleh mikrokontroler terhadap kinerja dari dosing pump dalam mensuplai cairan asam masuk ke dalam akuarium. Cairan asam ini bertujuan untuk menetralkan $\mathrm{pH}$ akuarium ketika meningkat lebih dari 7,5. Kontrol otomatis ini menggunakan pengendali proporsional. Masukan atau (set point) diatur bernilai $\mathrm{pH} 7,5$. Blok diagram dapat dilihat pada Gambar 1 .

Nilai error dapat dicari dengan mengurangi nilai referensi dengan nilai pembacaan sensor seperti persamaan ini:

\section{Error $=$ set point $-\mathrm{pH}$ sensor}

Dari persamaan diatas dapat diketahui ketika pembacaan $\mathrm{pH}$ dari sensor semakin tinggi dari set point $(7,5)$ maka akan menyebabkan nilai error semakin besar.

Setelah nilai error didapatkan kemudian nilai tersebut dimasukan ke rumus matematis berikut ini:

$$
\mathrm{P}=\mathrm{Kp} \times \text { error }
$$

Nilai dari "P" tersebut yang akan menjadi nilai dari PWM (Pulse Width Modulation) yang akan mengatur duty cycle dari dosing pump saat bekerja. Semakin tinggi nilai error maka akan semakin besar nilai duty cycle yang dihasilkan oleh mikrokontroler.

Jika terjadi perubahan terhadap sinyal masukan akan menyebabkan sistem secara langsung mengubah keluaran konstanta pengalinya [16].

\section{F. Diagram Blok}

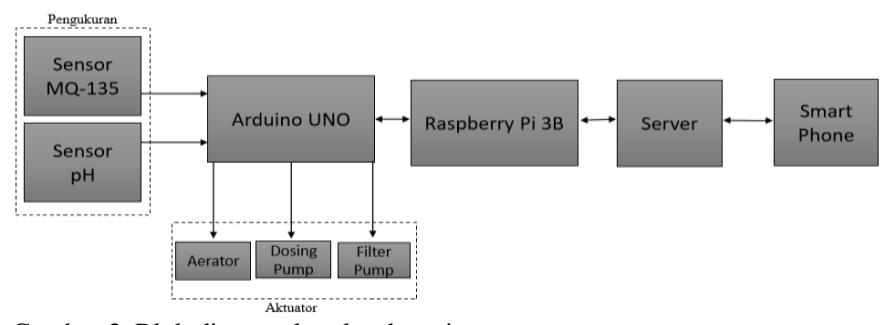

Gambar 3. Blok diagram keseluruhan sistem.

Seperti yang telah ilustrasikan oleh gambar 2 bahwa secara keseluruhan sistem ini berfungsi untuk memonitor dan mengontrol kadar amonia yang berbasis IoT (Internet of Thing). Pada gambar 3 menunjukan diagram blok sistem secara keseluruhan. Pengiriman data ini dimulai dengan pembacaan nilai $\mathrm{pH}$ dan amonia oleh sensor $\mathrm{pH}$ dan sensor MQ-135. Hasil pengukuran sensor yang telah diolah datanya oleh Arduino tersebut dikirimkan menuju single board computer (Raspberry Pi 3B) dan kemudian menggunakan metode API Endpoint yang ditembakan pada suatu link PHP basis data yang telah dibuat pada server. Kemudian data tersebut disimpan pada basis data yang berada di server dan data yang telah disimpan pada basis data tersebut diunduh oleh aplikasi pada smartphone untuk ditampilkan. Data yang ditampilkan pada smart phone ini merupakan data ter-update yang ada di basisdata dengan kata lain data tersebut adalah data hasil pembacaan terbaru yang diukur oleh kedua sensor tersebut. Data pembacaan dari smart phone akan selalu diperbarui (update) dalam rentang waktu 10 detik. Selain itu pada aplikasi smartphone juga memiliki fitur kontrol manual, 
yaitu menyalakan dan mematikan aerator dan filter air pada akuarium. Proses kontrol manual ini juga dengan menggunakan bantuan dari basis data pada server yang nantinya akan diakses oleh Raspberry dan Arduino yang akan mengeksekusi perintah yang diberikan lewat smart phone.

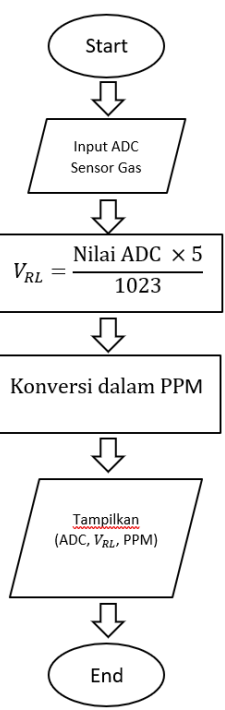

Gambar 4. Flowchart Kalibrasi Sensor MQ-135.

\section{G. Raspberry Pi $3 B$}

Raspberry Pi, sering disingkat dengan nama Raspi, adalah komputer papan tunggal (single-board circuit; SBC) yang seukuran dengan kartu kredit yang dapat digunakan untuk menjalankan program perkantoran, permainan komputer, dan sebagai pemutar media hingga video beresousi tinggi. Raspberry Pi dikembangkan oleh yayasan nirlaba, Rasberry Pi Foundation, yang digawangi sejumlah pengembang dan ahli komputer dari Universitas Cambridge, Inggris[15].

Pada penelitian ini yang menggunakan Raspberry Pi yang bertujuan untuk sebagai media penerima informasi berupa data sensor yang nantinya data sensor tersebut akan dikirimkan menuju server dan basis data. Selain itu penggunaan raspberry ini juga sebagai penerima intruksi perintah dari smartphone untuk menyalakan dan mematikan aktuator-aktuator yang digunakan.

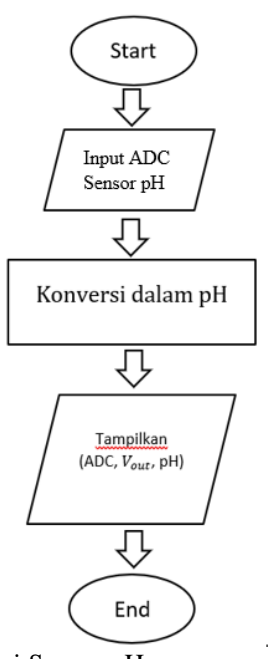

Gambar 5. Flowchart Kalibrasi Sensor pH

\section{H. Perancangan Konversi ADC Menjadi PPM Sensor} Amonia

Sensor Amonia adalah sensor semikonduktor yang memiliki input tegangan 5 volt DC, dan memili nilai keluaran berupa ADC. Nilai ADC tersebut akan dikonversikan ke dalam PPM (Part Per Million), maka diperlukan data berupa Vout dari sensor gas amonia. ADC tersbut yang nantinya akan diproses oleh mikrokontroler Arduino UNO yang memiliki ADC 110 bit. Perhitungan tegangan ADC (Analog to Digital Converter) dapat dirumuskan pada persamaan 3:

$$
\text { Tegangan ADC }=\frac{\text { Fin } x 1024}{\text { Vref }}
$$

Untuk dapat dikonversi kedalam satuan ppm maka diperlukan model matematis, seperti yang ditunjukan pada flowchart dibawah ini.

\section{Perancangan Konversi Nilai ADC Sensor $\mathrm{pH}$}

Sensor $\mathrm{pH}$ adalah sensor yang digunakan untuk mengukur kualitas suatu air, dengan cara melihat derajat keasaman. Tegangan masukan sensor $\mathrm{pH}$ adalah 5 volt DC, dan memiliki keluaran berupa nilai ADC. Nilan ADC tersebut akan dikonversikan ke dalam satuan $\mathrm{pH}$. Arduino nantinya akan memproses ADC tersebut dengan ADC 10 bit. Perhitungan tegangan ADC (Analog to Digital Converter) dapat dirumuskan dengan persamaan 3 :

Untuk dapat dikonversi kedalam satuan ppm maka diperlukan model matematis, seperti yang ditunjukan pada flowchart dibawah ini.

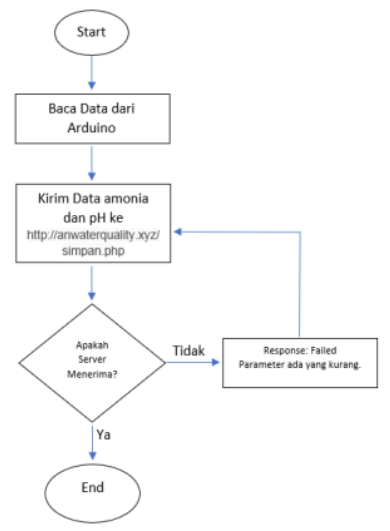

Gambar 6. Flowchart proses pengiriman data ke basisdata.

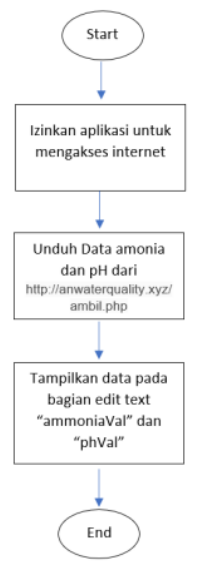

Gambar 7. Flowchart penerimaan data pada aplikasi. 


\section{J. Perancangan Pengiriman Data ke Smartphone}

Pengiriman data dilakukan melalui Raspberry Pi 3B berdasarkan data yang telah diolah oleh Arduino. Data yang diterima dari Arduino pertama akan dikirim menuju server. Kemudian akan disimpan pada basisdata, setelah basisdata berhasil menyimpan data tersebut, kemudian aplikasi pada smartphone bias mengakses data yang berada pada basisdata tersebut. Data yang akan ditampilkan oleh smartphone hanya data terbaru yang berhasil disimpan pada basisdata oleh Raspberry. Gambar 6 dan 7 adalah flowchart dari sistem pengiriman dan penerimaan data.

\section{HASIL DAN DISKUSI}

\section{A. Pengujian Kalibrasi Sensor Amonia}

Rangkaian dari sensor MQ-135 merupakan rangkaian pembagi tegangan dengan sumber tegangan sebesar 5 volt DC, sedangkan nilai tegangan yang dikeluarkan oleh sensor MQ135 adalah nilai yang digunakan dalam proses kalibrasi agar dapat di konversi menjadi PPM (Part per Million). Proses pengujian dilakukan dalam sebuah wadah tempat tertutup dengan melakukan pengujian kalibrasi sensor amonia.

Pada sensor gas amonia MQ-135 proses kalibrasi sensor ini dapat menggunakan informasi-informasi yang ada di datasheet.

Pada MQ-135 terdapat RL (Load Resistance) yang berada diantara ground dan VRL. Sedangkan pada modul sensor secara langsung dapat diukur nilai dari RL.

Pada gambar 8 pengukuran secara langsung dilakukan pada modul sensor gas amonia MQ-135 dan didapatkan nilai dari RL adalah sebesar $10 \mathrm{k}$ ohm, hal ini sesuai karena pada datasheet dikatakan besaran untuk RL pada sensor MQ-135 yaitu kisaran 10k ohm sampai 47k ohm. Setelah mendapatkan harga dari RL, kemudian kembali kepada acuan datasheet, pada datasheet terdapat grafik karakteristik sensitivitas dari sensor MQ-135 yang dapat dilihat pada Gambar 8.

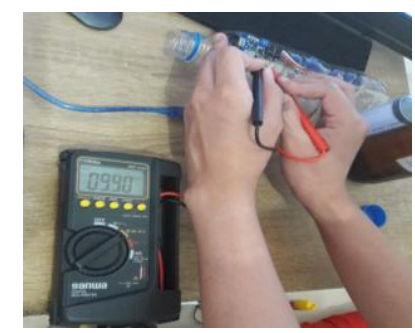

Gambar 8. Pengukuran RL pada Modul Sensor.

Tabel 1.

Data Hasil Karakteristik Sensor MQ-135

\begin{tabular}{cccc}
\hline \hline No. & $\begin{array}{c}\text { Tegangan } \\
\text { MQ-135 } \\
\text { (volt) }\end{array}$ & $\begin{array}{c}\text { MQ-135 } \\
\text { (PPM) }\end{array}$ & $\begin{array}{c}\text { Volume } \\
\text { (cc) }\end{array}$ \\
\hline 1 & 0.21 & 2,33 & 0 \\
2 & 0,26 & 4,14 & 10 \\
3 & 0,29 & 5,41 & 20 \\
4 & 0,34 & 7,74 & 30 \\
5 & 0,43 & 14,12 & 40 \\
6 & 0,45 & 16,35 & 50 \\
7 & 0,47 & 18,30 & 60 \\
8 & 0,58 & 32,5 & 70 \\
9 & 0,65 & 45,0 & 80 \\
\hline \hline
\end{tabular}

Pada grafik tersebut terdapat perbandingan antara ppm dengan Rs/Ro. Dapat dilihat pada grafik bahwa rasio resistansi fresh air yaitu konstan. Berarti berdasarkan grafik dapat diperkirakan bahwa nilai Rs/Ro adalah:

$$
\mathrm{Rs} / \mathrm{Ro}=3,6
$$

Dari datasheet kita dapat mengetahui formula untuk menghitung dan mendapatkan nilai Rs, yaitu dengan rumus sebagai berikut:

Resistansi Sensor (Rs): Rs = (Vc/VRL-1)xRL (5)

Berdasarkan rumus diatas kita telah mengetahui bahwa nilai dari $\mathrm{Vc}$ yang berarti tegangan sumber $(+5 \mathrm{~V})$ dan nilai $\mathrm{RL}$ yang telah diukur adalah 10k ohm. Kemudian untuk mendapatkan nilai Rs menggunakan program Arduino. Hasil dari pengukuran Ro adalah sekitar 50K.

Kemudian untuk nilai dari Rs (resistansi sensor) menggunakan persamaan 3 dan dikalkulasikan pada program Arduino didapatkan nilai Rs yaitu sekitar 250K.

Hubungan antara Rs/Ro dan PPM adalah logaritmik, yang dapat direpresentasikan dengan rumus dibawah ini:

$$
\log (\mathrm{y})=\mathrm{m} * \log (\mathrm{x})+\mathrm{b}
$$

Untuk menentukan nilai dari $\mathrm{m}$ dan $\mathrm{b}$ dapat ditentukan dua titik $(x 1, y 1)$ dan $(x 2, y 2)$ pada grafik fungsi NH3. Sehingga kedua titik ditentukan pada $(19,2)$ dan $(100,1)$.

$\mathrm{m}=[\log (\mathrm{y} 2)-\log (\mathrm{y} 1)] /[\log (\mathrm{x} 2)-\log (\mathrm{x} 1)]$

$\mathrm{m}=\log (1 / 2) / \log (100 / 19)$

$\mathrm{m}=-0.417$

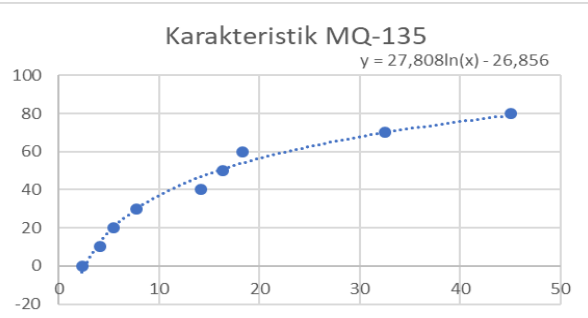

Gambar 9. Grafik Hasil Pengukuran Karakteristik MQ-135.

Tabel 2.

Hasil Pembacaan Sensor ADC Sensor pH Terhadap Buffer

\begin{tabular}{ccc}
\hline \hline No & Nilai ADC & Buffer $\mathrm{pH}$ \\
\hline 1 & 312 & 4 \\
2 & 365 & 7 \\
3 & 424 & 10 \\
\hline \hline
\end{tabular}

Kemudian untuk mendapatkan nilai $b$ titik yang diambil adalah titik tengah $(40,1.55)$

$\mathrm{b}=\log (\mathrm{y})-\mathrm{m} * \log (\mathrm{x})$

$\mathrm{b}=\log (1.55)-\mathrm{m} * \log (40)$

$\mathrm{b}=0.323$

Selanjutnya untuk mendapatkan PPM menggunakan rumus dibawah ini:

$$
\mathrm{PPM}=10^{\wedge}\{[\log (\text { ratio })-\mathrm{b}] / \mathrm{m}\}
$$

Pada pembacaan sensor untuk mendapatkan PPM seluruh hasil perhitungan pada kalibrasi awal dimasukan kedalam program dan diinisialisasikan.

\section{B. Pengujian Karakteristik MQ-135}

Pengujian karakteristik terhadap sensor amonia MQ-135 ini bertujuan untuk melihat respon dari sensor amonia ini terhadap gas amonia yang diberikan secara berkala. Pemberian 
gas amonia ini secara bertahap dalam sebuah wadah tertutup, data hasil pengukuran dapat dilihat pada tabel 1 .

\section{Penentuan Model Matematis Kalibrasi Sensor PH}

Metode yang digunakan untuk melakukan kalibrasi pada sensor $\mathrm{pH}$ yaitu dengan regresi liner dengan rumus matematis:

$$
\mathrm{Y}=\mathrm{a}+\mathrm{bX}
$$

Dengan metode regresi linier didapatkan persamaan matematis yang dapat mewakili gambar 10 , yaitu:

$$
Y=-12.642+0,0535 \times X
$$

\section{Perbandingan $\mathrm{pH}$ buffer dengan Hasil Pembacaan Sensor}

Untuk dapat mencari nilai dari error tersebut, maka dapat menggunakan persamaan dibawah ini:

$$
\text { Error }=\frac{\mid p H \text { sebenarnya }-p H \text { sensor } \mid}{\text { ph sebenarnya }} \times 100 \%
$$

Keluaran dari sensor $\mathrm{pH}$ ini berupa ADC yang dikonversikan menjadi satuan $\mathrm{pH}$, pada Tabel 3 menunjukan bahwa terdapat error rata-rata pembacaan $1,88 \%$ atau selisih 0.08-0.15 pembacaan $\mathrm{pH}$ terhadap buffer $\mathrm{pH}$.

\section{E. Pengujian Fitur Monitoring}

Pada gambar 11 menunjukan hasil pengiriman data dari basis data menuju aplikasi smartphone melalui koneksi internet dapat berjalan dengan benar. Data yang ditampilkan pada smartphone ini adalah data dari penyimpanan pada tabel basis data yang paling akhir. Dengan kata lain Query yang ditampilkan adalah data dengan ID yang paling besar. Pada gambar 11 menunjukan Query yang ditampilkan yaitu dengan ID 1537 yang menyimpan data pengukuran pada tabel amonia 56,76 dan $\mathrm{pH} 5,66$. Kemudian data yang ditampilkan pada smartphone yaitu data yang sesuai dengan ID 1537 atau data yang paling baru disimpan pada basis data.

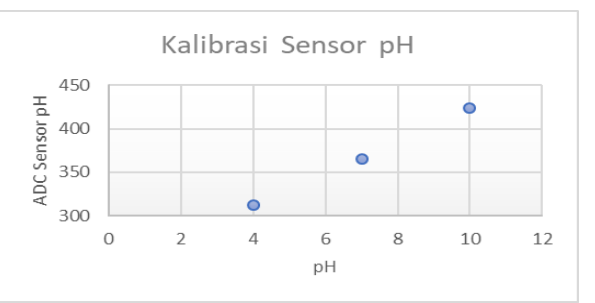

Gambar 10. Grafik Kalibrasi Sensor.

Tabel 3.

\begin{tabular}{ccccc}
\multicolumn{5}{c}{ Perbandingan Nilai Pembacaan Sensor dengan Buffer. } \\
\hline \hline No. & $\begin{array}{c}\text { Sensor } \mathrm{pH} \\
(\mathrm{pH})\end{array}$ & $\begin{array}{c}\text { Buffer } \mathrm{pH} \\
(\mathrm{pH})\end{array}$ & $\begin{array}{c}\text { Selisih } \\
(\mathrm{pH})\end{array}$ & Error $(\%)$ \\
\hline 1 & 3,91 & 4 & 0,08 & 2 \\
2 & 6,85 & 7 & 0,15 & 2,14 \\
3 & 9,85 & 10 & 0,15 & 1,5 \\
& Rata-rata & & 0,126 & 1,88 \\
\hline \hline
\end{tabular}

\section{F. Pengujian Keseluruhan Sistem}

Pada pengujian keseluruhan sistem, dilakukan percobaan untuk menyalakan aerator dan filter air secara manual melalui aplikasi smartphone. Aerator dan filter air yang pada awalnya dalam kondisi mati dapat dinyalakan dengan baik melalui aplikasi smartphone. Selain melakukan pengujian terhadap kontrol manual sistem. Diberikan juga pengujian terhadap kontrol otomatis dan monitoring pada keseluruhan sistem dengan menyimulasikan suatu permasalahan pada akuarium, yaitu dengan dilakukan percobaan menaikan kadar $\mathrm{pH}$ pada akuarium, seperti yang ditunjukan pada tabel 4. Pada percobaan ini mula-mula dilakukan pengukuran terhadap $\mathrm{pH}$ air akuarium.

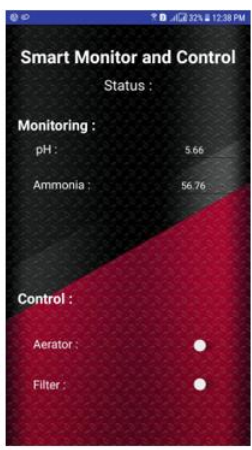

Gambar 11. Tampilan Basisdata Sensor dan Aplikasi.

Pada pengukuran didapatkan bahwa $\mathrm{pH}$ air pada akuarium bernilai 8.92 dan amonia yang terukur sebesar $5.92 \mathrm{ppm}$. Tabel 4 menunjukan hasil monitor terhadap akuarium. Kemudian sistem kontrol mulai dinyalakan yang berdampak bekerjanya dosing pump dalam memompa cairan asam menuju akuarium. Kinerja dari dosing pump tersebut bergantung terhadap keluaran dari pengendali proporsional terhadap kenaikan pH. Dalam waktu 10 detik, pH mengalami penurunan menjadi 7.37 dan terdapat sedikit kenaikan pembacaan sensor amonia menjadi $6.31 \mathrm{ppm}$. Kemudian 10 detik berikutnya pengukuran dari sensor $\mathrm{pH}$ menunjukan penurunan dari $\mathrm{pH}$ secara drastis menjadi 5,71. Hal ini dapat dikarenakan kesalahan dari sistem kontrol yang menyebabkan air pada akuarium menjadi terlalu asam.

Tabel 4.

\begin{tabular}{ccc} 
& Hasil Pengukuran Sistem \\
\hline \hline ID & $\mathrm{pH}$ & Amonia \\
2452 & 8.92 & 5.92 \\
2453 & 8.86 & 4.55 \\
2454 & 8.81 & 6.05 \\
2455 & 7.37 & 6.31 \\
2456 & 5.6 & 7.86 \\
2457 & 5.6 & 8.33 \\
2458 & 5.71 & 13.9 \\
2459 & 6.14 & 7.56 \\
2460 & 6.83 & 6.83 \\
2461 & 7.47 & 13.01 \\
2462 & 7.87 & 13.75 \\
2463 & 7.98 & 13.95 \\
2464 & 7.47 & 13.01 \\
2465 & 7.37 & 12.79 \\
2466 & 7.17 & 8.64 \\
2467 & 7.05 & 8.3 \\
2468 & 6.9 & 6.75 \\
\hline \hline
\end{tabular}

Kemudian percobaan selanjutnya ditambahkan kembali cairan amonia kedalam akuarium. Hal ini dilakukan untuk melihat respon dari sistem kontrol otomatis jika terjadi kenaikan $\mathrm{pH}$. Hasilnya pada saat diberikan amonia cair kedalam akuarium, sensor gas amonia lebih cepat mendeteksi kenaikan amonia pada akuarium dari pada sensor $\mathrm{pH}$ dalam mendeteksi kenaikan $\mathrm{pH}$ yang terjadi. Selanjutnya nilai dari pembacaan sensor gas lebih cepat mendeteksi kenaikan amonia ketika diberikan amonia cair pada akuarium, menjadi $13.9 \mathrm{ppm}$ sedangkan sensor $\mathrm{pH}$ masih mendeteksi nilai $\mathrm{pH}$ sebesar 5.71. Hal ini terjadi dikarenakan ketika diberikan amonia cair, air pada akuarium belum sepenuhnya tercampur 
dengan amonia tersebut. Sehingga $\mathrm{pH}$ yang terukur masih bernilai 5.71 .

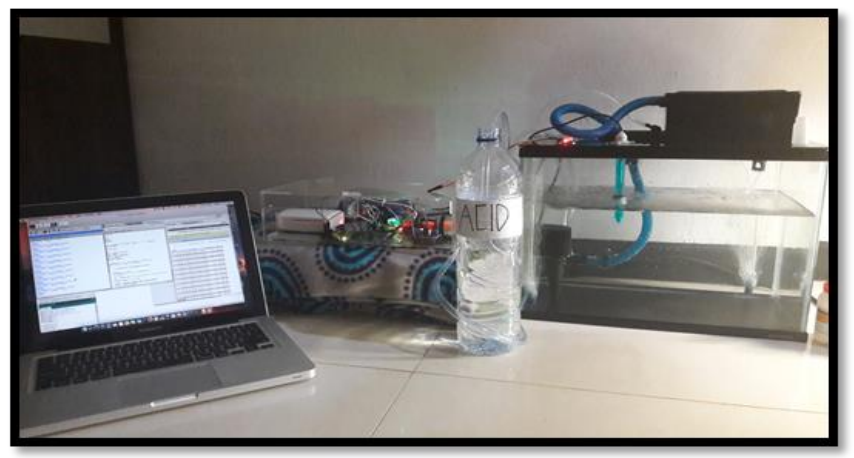

Gambar 12. Alat monitoring dan kontrol.

Setelah menunggu kurang dari 10 detik $\mathrm{pH}$ berangsur naik menjadi 7.47 dan amonia mengalami penurunan menjadi $13.01 \mathrm{ppm}$. Kemudian 10 detik berikutnya $\mathrm{pH}$ kembali naik menjadi 7,98 dan amonia bernilai 13,95 ppm. Pada kondisi ini kontrol otomatis akan bekerja dalam menyalurkan cairan asam menuju akuarium, hasilnya 10 detik berikutnya $\mathrm{pH}$ dan amonia mengalami penurunan menjadi 7.47 dan $13.01 \mathrm{ppm}$. Selanjutnya nilai $\mathrm{pH}$ berangsur-angsur mengalami penurunan menuju pada nilai yang netral pada akuarium dan bergitu pula dengan kadar gas amonia yang terukur. Setelah beberapa saat pengukuran terakhir yang ditunjukan pada aplikasi yaitu nilai pH sebesar 6.9 dan nilai amonia sebesar $6.75 \mathrm{ppm}$. Gambar 12 merupakan keseluruhan alat monitoring dan kontrol yang telah dibuat.

\section{KESIMPULAN/RINGKASAN}

Berdasarkan pengujian yang telah dilakukan pada penelitian bahwa sistem monitoring dan kontrol ini memiliki beberapa fitur yaitu seperti monitoring kadar amonia dan $\mathrm{pH}$, fitur kontrol otomatis terhadap $\mathrm{pH}$, dan fitur kontrol manual terhadap aktuator melalui aplikasi. Pada keseluruhan sistem memiliki delay dalam penampilan data dan pemberian instruksi dari smartphone sebesar 10 detik.

\section{DAFTAR PUSTAKA}

[1] Y. Hikmayani et al., "Evaluasi Kebijakan Peningkatan Produksi Perikanan Budidaya," 2012.

[2] R. W. Haliman and D. Adijaya., Udang vannamei, Pembudidayaan dan Prospek Pasar Udang Putih yang Tahan Penyakit. Jakarta: Penebar Swadaya, 2005.

[3] G. Wiranto and I. D. P. Hermida, "Pembuatan Sistem Monitoring Kualitas Air secara Real Time dan Aplikasinya dalam Pengelolaan Tambak Udang," Teknol. Indones., vol. 33, no. 2, Nov. 2012.

[4] E. Susanti and J. Triyono, "Prototype Alat IoT (Internet Of Things) untuk Pengendali dan Pemantau Kendaraan Secara Realtime,” Dec. 2016.

[5] J. Ogbonna and A. Chinomso, "Determination of The Concentration of Ammonia That Could Have Lethal Effect on Fish Pond," vol. 5, no. 2, 2010.

[6] "Rancang Bangun Alat Ukur Ph dan Suhu Berbasis Short Message Service (SMS) Gateway."

[7] A. TOMI, "Sistem Monitoring PH dan Suhu Air dengan Transmisi Data Nirkabel," Undergrad. Thesis Electr. Eng. RSE 681.76 Adi s, 2011, 2011.

[8] B. Wicaksono, B. A. Wicaksono, M. Rivai, and T. Tasripan, "Rancang Bangun Sistem Pencacah Frekuensi Untuk Sensor Gas Quartz Crystal Microbalance," J. Tek. ITS, vol. 3, no. 1, pp. F79F83, Mar. 2014.

[9] M. Gumelar, M. Rivai, and Tasripan, "Rancang Bangun Wireless Electronic Nose Berbasis Teknologi Internet of Things," J. Tek. ITS, vol. 6, no. 2, 2017.

[10] M. S. Ramadhan and M. Rivai, "Sistem Kontrol Tingkat Kekeruhan pada Aquarium Menggunakan Arduino Uno," J. Tek. ITS, vol. 7, no. $1,2018$.

[11] M. Ichwan, M. Gustiana Husada, M. Iqbal, and A. Rasyid, "Pembangunan Prototipe Sistem Pengendalian Peralatan Listrik pada Platform Android," 2013. 